\title{
A Course Project: An Overview from the PBL "as-Research-Oriented" Viewpoint
}

\author{
Juan Carlos Soto Merino \\ Department of Applied Mathematics, School of Technical Engineering, \\ University of the Basque Country UPV/EHU, Spain
}

\section{Introduction}

Problem resolution in Engineering and Experimental Sciences, as a research-oriented teaching methodology, is useful in cognitive-constructivist environments. This technique is reported in this chapter to show to the student the major phases of an Algebra course applied to typical situations of the syllabus, which have previously been characterized as completely open problems. The world today is characterized by rapid change. A number of factors necessitate an educational environment, significantly different. The current trend is that we are moving towards a learning society, and this involves a displacement towards a learner-centred education. There is also a change in the concept of continuing education, where the individual needs to be able to handle knowledge, update, select what is appropriate for a given context, to understand what has been learned so that it can be adapted to new, and rapidly changing, situations. Likewise, the change must be reflected in the assessment to the student, which should be focused on 'declarative knowledge' as a dominant reference. This paradigm shift should affect other features such as the approach of educational activities and teaching materials, which should lead to a variety of 'teaching situations' to encourage the student's compromise (Savin-Baden, 2000).

Any situation can only be conceived as a problem to the extent that there is a recognition of it as such a problem, that is, it is unknown, and to the extent that, a priori, we do not have the solution: a situation for which there is no obvious solution. But, it is desirable that students learn to solve problems raised at the university level, starting from open, and of interest, statements which include aspects from Science, Technology and Society fields. Solving a problem is to find a path where there previously was not a known one, finding a way to a difficult situation, to overcome an obstacle, to achieve a goal that could not initially be reached. This technique is proposed to be applied to address an opened-statement problem, which will be the definition of the course project, each student has to raise in a course of Linear Algebra with competences in an Industrial Electronics Technical Engineering degree, where the aim is to consider the student's meaningful learning. We analyze the possibilities of a course project based on the PBL methodology for teaching problem solving (Barrows, 2006): its strengths and its weaknesses are emphasized. In other words, we conceive the 
possibility of proposing a vision for overcoming the teaching methods of problem solving in Science and Engineering, which in line with the model of learning as a research-oriented, leads to a methodological change in a way that the students arrive to be able to cope more successfully open-statement problems. The proposal is not characterized by dramatic changes in the structure of the education system but for qualitative changes in the teaching strategies used in the classroom, the activities proposed by the students and by the sequencing of conceptual and methodological contents.

The problem resolution by students (which are accustomed to implement the proposed model) features closely the characteristics of the 'scientific work' and increase its effectiveness as resolvents. The procedural knowledge involves declarative knowledge specific to the area, and at the same time, the acquisition of the declarative knowledge is a process of construction that makes implicit or explicit use of procedural knowledge. It is therefore reasonable to expect that a further development of those procedures could lead to a more comprehensive learning and greater efficiency in the resolution.

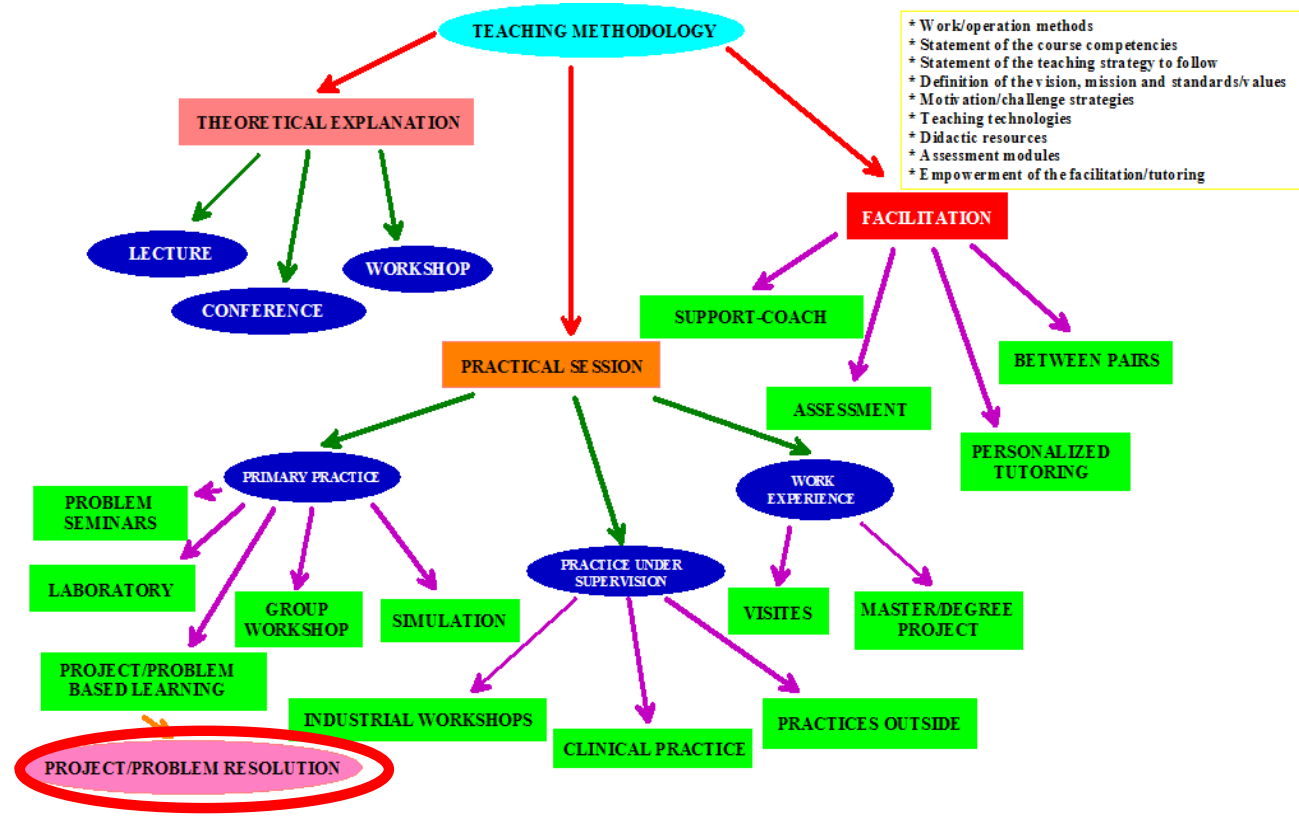

Fig. 1. The teaching methodologies.

\section{The problem statement}

The world today is characterized by rapid change. A number of factors such as globalization, the impact of information technology and communication, and the need for sponsoring and managing diversity necessitate an educational environment, significantly different. The current trend (associated with the European Higher Education Area -EHEA) is that we are moving towards a learning society, and this involves the displacement of an education that 
focuses on education towards a learner-centred education. Interest in the development of expertise in educational programs corresponds to an approach to education primarily focused on the student and their ability to learn, requiring to him more prominence and more compromise (Albert, 2007). There is also a change in the concept of continuing education, where the individual needs to be able to handle knowledge, update, select what is appropriate for a given context, to understand what has been learned so that it can be adapted to new, and rapidly changing, situations. It will then need to reduce the use of class-present tasks and enhance the class-non-present tasks to 'teach to learn' so that the student can 'learning to learn' perceiving higher education as a further stage of 'learning over a lifetime' (long-life-learning) (Castillo and Polanco, 2007).

Clearly, the changing role of the teacher being the person who structured the learning process, the major player in education, as well as supervising the work of the students, whose knowledge he evaluated, in the vision centred in the student, the teacher is now a companion in the process of learning, which helps the studying to achieve certain competences. While the role of the teacher remains critical, it moves increasingly toward an advisor, guide and motivator (i.e., this is the well-known metaphor of the thesis director and the novel researcher) (Fig. 1).

Likewise, the change must be reflected in the assessment of the student, which should be focused on 'declarative knowledge' as a dominant reference, and often it only happens to include an assessment based on the skills, capabilities and processes closely related to work and to the activities that lead to the student's progress (the need for continuous evaluation). Therefore, this paradigm shift should affect other aspects such as the approach of educational activities and teaching materials, which should lead to a variety of 'teaching situations' to encourage the student's compromise. This leads to the unavoidable conclusion that the learning-teaching paradigm is changing (Fullan, 2002).

\section{What does a problem mean?}

Any situation can only be conceived as a problem to the extent that there is a recognition of it as such a problem, that is, it is unknown, and to the extent that, a priori, we do not have the solution: a situation for which there are no obvious solution. Accordingly, a problem can be defined as a situation such that there are no obvious solutions. But it is desirable that students learn to solve problems raised at the university level, starting from open, and of interest, statements which include aspects from CTS (Science, Technology and Society). The choice of problematic situations should be done so as to embody a challenge affordable by the students so that through interaction and the help of others, the student can participate in the learning process (Brockband \& McGill, 2003)). Solving a problem is to find a path where there previously was not a known one, finding a way to a difficult situation, to overcome an obstacle, to achieve a goal that could not initially be reached. 


\begin{tabular}{c|c|c|c}
\hline $\begin{array}{c}\text { THEMATIC } \\
\text { UNIT }\end{array}$ & $\begin{array}{c}\text { MATHEMATICAL GROUNDS II (LINEAR ALGEBRA) } \\
\left(1^{\text {st }} \text { course, } 1^{\text {st }} \text { semester) }(6.0 \text { ECTS })\right.\end{array}$ & \multicolumn{2}{|c}{$\begin{array}{c}\text { WEIGHT } \\
(\%)\end{array}$} \\
\hline $\mathbf{1}$ & FINITE DIMENSION VECTOR SPACES & 10.00 & \\
$\mathbf{2}$ & MATRIX ALGEBRA & 10.00 & \\
$\mathbf{3}$ & LINEAR EQUATION SYSTEMS & 15.00 & $\mathbf{6 5 . 0 0}$ \\
$\mathbf{4}$ & EUCLIDEAN VECTOR SPACES & 20.00 & \\
$\mathbf{5}$ & SPECTRAL THEORY & 10.00 & \\
$\mathbf{6}$ & Practical applications in the Mathematica programming & & \\
& environment & & $\mathbf{1 5 . 0 0}$ \\
& by using algebraic and numerical techniques & & \\
\hline 7 & (5 two-hour practical sessions) & & $\mathbf{2 0 . 0 0}$ \\
\hline
\end{tabular}

Fig. 2. The syllabus of Mathematical Grounds (tasks-based).

This technique is proposed to be applied to address an opened-statement problem, which will be the definition of the course project, each student has to raise in a course of Linear Algebra (Figs. 2-3) with competences in an Industrial Electronics Technical Engineering grade, where the aim is to consider the student's meaningful learning. The weight of the research work is important in monitoring the formative and additive assessment of the course: this is why special attention is devoted (Stake, 2004). To do so, students must apply the scientific method and the problem-solving methodology to develop the skills that are inherent. It is not an exclusive method, but one more training methodology, while in the strategic resources within the daily teaching practice implementation (McKernan, 1999; Fullan, 2002; Michavilla, 2006; Castillo and Polanco, 2007).

\begin{tabular}{|c|c|c|c|}
\hline COMPETENCE & $\begin{array}{l}\text { MATHEMATICAL GROUNDS II } \\
\text { (LINEAR ALGEBRA) (6.0 ECTS) }\end{array}$ & $\begin{array}{l}\text { NUMBER OF } \\
\text { CRITERIA FOR } \\
\text { MEASURABLE } \\
\text { OUTCOMES } \\
\end{array}$ & $\begin{array}{c}\text { WEIGHT } \\
(\%)\end{array}$ \\
\hline 1 & $\begin{array}{l}\text { Significant knowledge of the mathematical contents } \\
\text { from an algebraic and numerical approach with } \\
\text { practical applications from engineering fields }\end{array}$ & 3 & 15.00 \\
\hline 2 & $\begin{array}{l}\text { Numerical and symbolic modelling of linear } \\
\text { continuous time-invariant dynamic systems via } \\
\text { some professional programming environment }\end{array}$ & 2 & 10.00 \\
\hline 3 & $\begin{array}{l}\text { Obtaining of valid (reasoned and justified) } \\
\text { conclusions from the results by efficiently managing } \\
\text { the worked data }\end{array}$ & 8 & 40.00 \\
\hline 4 & $\begin{array}{l}\text { Design, implementation and management of a } \\
\text { research project which will be produced in a } \\
\text { collaborative team; then an scientific report will } \\
\text { must be presented }\end{array}$ & 5 & 30.00 \\
\hline 5 & $\begin{array}{l}\text { To establish strategies and mechanisms to improve } \\
\text { the learning quality through significant trainings } \\
\text { and NICTs by considering policies such as } \\
\text { sustainability, thrift, ethics, human rights, diversity, } \\
\text {... and so on }\end{array}$ & 3 & 10.00 \\
\hline
\end{tabular}

Fig. 3. The syllabus of Mathematical Grounds (competences-based). 
The learning methodology, that is suggested in the sequel, shows undergraduates develop the competences involved (Fig. 3), but a lot care must be considered.

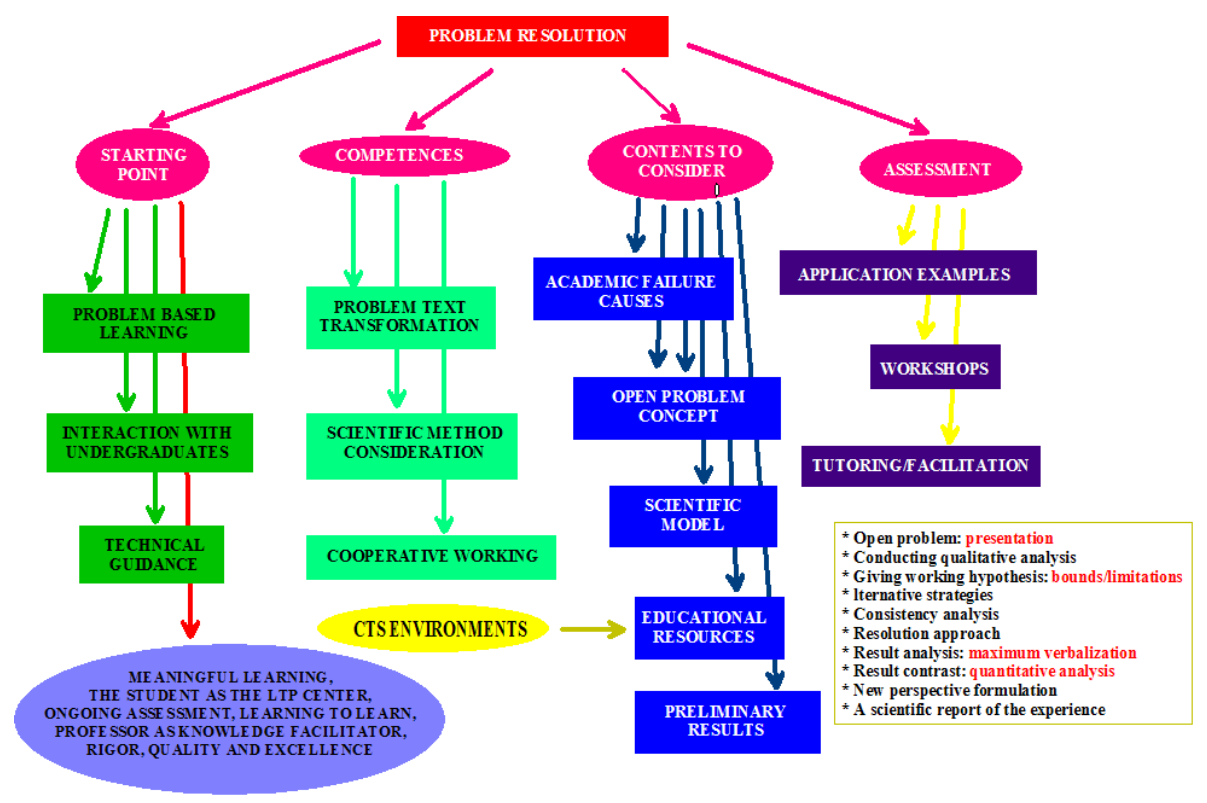

Fig. 4. Problem solving via the PBL approach.

\section{Problem solving}

The applied scientific method is based on a cognitive-constructivist (Osborne-Wittrock's approach) concept of the learning environment (figures 4-5) to produce significant learning (Phillips, 1995; Wertz et al., 2005): (1) the appropriate definition of the problem under consideration, with a discussion of the problem interest raised in connection with the descriptors of the course subjects; (2) the adequate knowledge of the physical mechanisms, describing the process being worked; (3) the statement of the objectives of the study (qualitative analysis stage), as well as the detection of the conditions that define the problem; (4) the generation of hypotheses for creative speculation; (5) the search for a solution, developing different methodologies and strategies; (6) the contrast interpretation of the results obtained; (7) analyzing other possible extensions of the study, and (8) the development of the corresponding writing and speech, according to a particular pattern (for example, a scientific article). To fix the experience reported in this paper the photoelectric effect will be considered. Afterwards, some more examples will be provided as work references.

2007's timing PBL is presented in Fig. 6 (detailed information is provided in figure 8). The students' team carries out the diverse stages of the research coached by the professor. The PBL approach application in the Course Project consists of designing and implementing a 
Research Project (namely, the photoelectric effect) as an open problem to work in teams, using the scientific method: a technological situation must be modelled to focus the descriptors, the resources and the algebraic methodologies of the syllabus. Also, the relationships with other subjects must be reflected as the competences are evolving while using the Deming's wheel (PDCA; i.e., Plan-Do-Check-Act) work system. As a consequence, the following steps are taking into account:

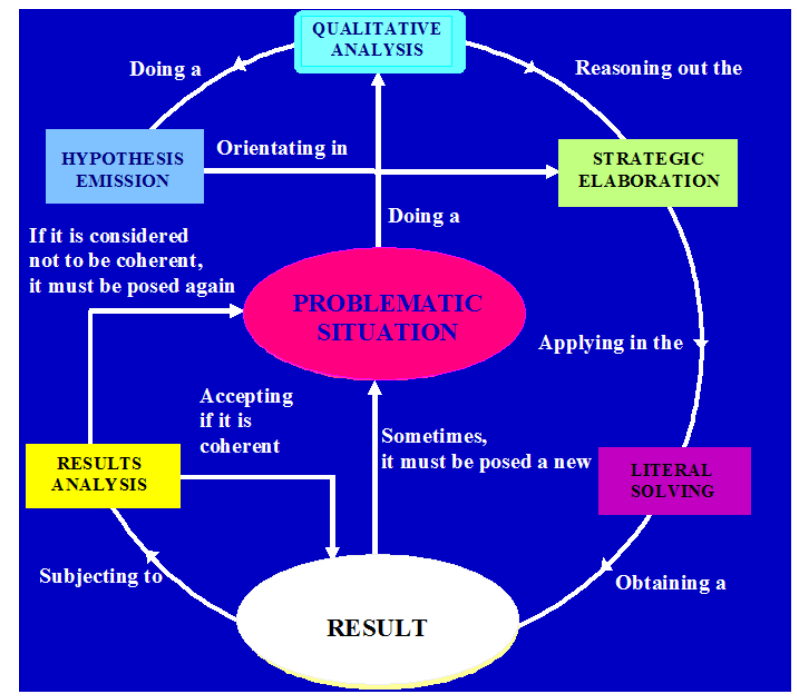

Fig. 5. The process oriented research.

S1: The Course Project is enunciated as an open problem by the team: The photoelectric effect sets up that the minimum voltage $(\mathrm{V})$ to make an electron to leave a surface is a function of the frequency $v(\mathrm{~Hz})$ of the incidental radiation and of a certain function $\phi$, which is characteristic of each surface. Looking at the existing literature, one must select several experimental data to estimate the values of the constants $h$ (Planck's constant) and $\phi$ so as to determine which such a surface is (Fig. 8).

S2: To take into account the PBL approach (Figs. 4, 5 and 7).

S3: To pose the problem via a matrix, vector or numerical modelling to establish the dependence between the existing variables $\left(e V_{0}=h v-\phi\right.$ being $v>v_{t}=\phi / h$ the minimum frequency). At the same time, the work hypotheses are established (Fig. 8).

S4: The theory key points must be revisited to have a good understanding: a concept map is usually provided with every unit as an information help. 
PHASE I

A. Documentation: subject guide and Course Project guide

B. Competencies declaration aims and expected outcomes

C. The assescanen procedue formative and stmmative evaluation

1 week

C. Understanding the comperencies to work (skills, aptitudes, attitudes, values, ...) and goals to be pursued

C. Understanding the competencies to work (skills, aptitudes, attitudes, values,
D. Discuss issues that are discussed in the subject course: links to other subjects

E. Looking for information: Find an example that meets the objectives and course contents

E. Describe the needs that the selected problem raises

F. Role playing Task distribution. Discriminate between the personal material resources that will be needed

G. Planning stages that are expected to be filled, for further evaluation and monitoring PHASE III

H. Gather all the theoretical elements necessary for developing the project memory

H. Gather all the theoretical elements necessary for developing the project memory
I. Analyse the problem: work hypothesis and hypothesis contrast, verification and feedback. Facilitation

J. Analyze what elements must be introduced to write the scientific essay

K. Prepare an outline of how the oral presentation of results will be

L. Perform the proper presentation of the literature and references to be used PHASE IV

M. Development of written essay and preparation the oral assertion

$\mathrm{N}$. Writing the essay, depending on the structure of a scientific article

o. Detailing the time and human resources employed on the basis of the previous role playing

P. To make a concept map of project development

Q. Develop a Gantt's chatt and task sequence timeline

$$
\text { PHASE V }
$$

R. Memory about the resource management

S. Preparation of documentation. which will be given to professor staff

I. Delivery of all required documentation

$$
\text { PHASE VI }
$$

U. Interview; defense of the project to the teacher and to the class

$v$. Assessment and facilitation
3 weeks

5 weeks

$$
\text { (n) }
$$

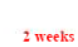

1 week

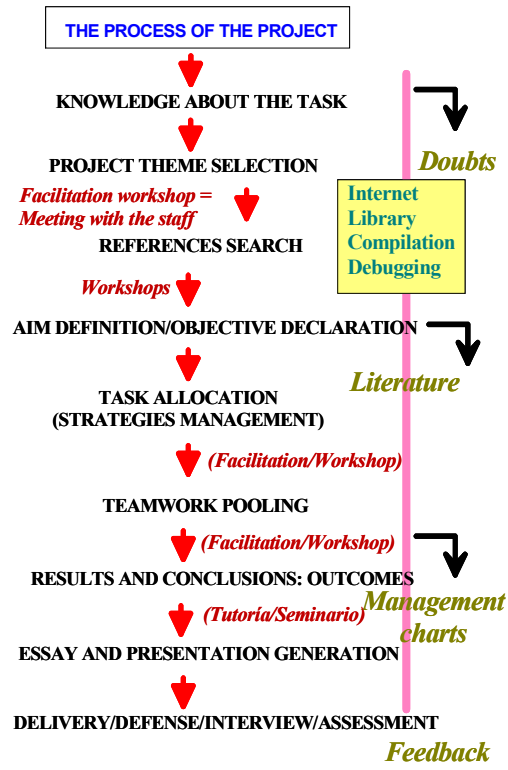

Fig. 6. The Course Project definition.

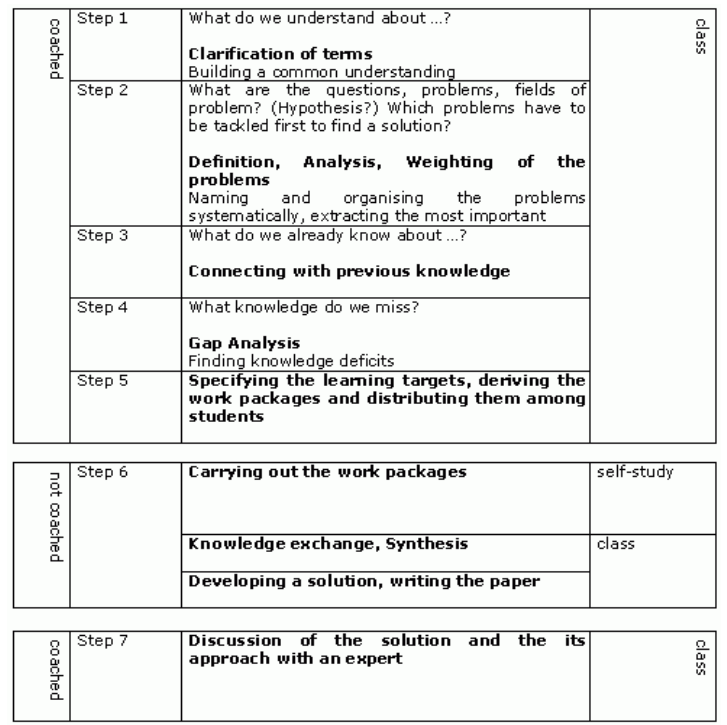

Fig. 7. The PBL approach working concept.

\begin{tabular}{ccccccc}
\hline$v\left(\mathrm{~Hz} \times 10^{-3}\right)$ & 56 & 70 & 79 & 83 & 102 & 120 \\
\hline $\mathrm{V}_{\mathbf{0}}(\mathrm{V})$ & 0.05 & 1.00 & 1.40 & 1.74 & 2.43 & 3.00 \\
\hline
\end{tabular}

Fig. 8. Experimental data for the photoelectric effect. 
S5: How the student can be coached to reach a true mathematical comprehension in order to determine the concept structure and the relationships of the involved mathematical units? (Figs. 6, 7 and 9).

\begin{tabular}{|c|c|c|c|c|c|c|}
\hline \multirow{2}{*}{$\begin{array}{l}\text { CODE } \\
\text { PDC }\end{array}$} & \multirow{2}{*}{ TASK TO IMPLEMENT } & \multirow{2}{*}{ ACTIVITIES TO DEVELOP } & \multirow{2}{*}{$\begin{array}{l}\text { OUTCOME TO } \\
\text { MEASURE/OBJECTIVE }\end{array}$} & \multicolumn{2}{|c|}{$\begin{array}{c}\text { ESTIMATED TIME } \\
\text { (hours) }\end{array}$} & \multirow{2}{*}{ DIFFICULTIES ENCOUNTERED } \\
\hline & & & & CLASSROOM & $\begin{array}{l}\text { NON- } \\
\text { ATTENDANCE }\end{array}$ & \\
\hline 1 & $\begin{array}{l}\text { - Presentation of the subject Teaching } \\
\text { Planning STP } \\
\text { Exp lanation of the teaching method that is } \\
\text { the base of the Course Project } \\
\text { - Text of Course Project as an open problem } \\
\text { This task is reminded from time to time to } \\
\text { ensure that students are a ware of what it } \\
\text { really means }\end{array}$ & $\begin{array}{l}\text {-Statement of competencies involved } \\
\text { in the Course Project } \\
\text { - Using simple examples for } \\
\text { explanation } \\
\text { - Defin ition of objectives } \\
\text { - Influence on the assessment }\end{array}$ & $\begin{array}{l}\text {-Specific questions specific in } \\
\text { tutoring/facilitation sessions and/or } \\
\text { classroom } \\
\text {-Use a daily log as a register diary }\end{array}$ & 0.25 & & $\begin{array}{l}\text { - The student feels that the documentation } \\
\text { (delivered on the first day of class) is } \\
\text { excessive } \\
\text {-The subject guide may be useful to overcome } \\
\text { this difficulty, if provided that it is very well } \\
\text { designed }\end{array}$ \\
\hline 2 & $\begin{array}{l}\text { Finding information in books, magazines, } \\
\text { specialised articles, reports, encyclopaedias } \\
\text { and /or the Internet, asking to other teachers } \\
\text { based on the descriptors of the subject, given } \\
\text { the first day of class }\end{array}$ & $\begin{array}{l}\text { The student looked for information on } \\
\text { the sources suggested }\end{array}$ & \multirow{3}{*}{$\begin{array}{l}\text { The student will deliver the } \\
\text { statement of the problem, that will } \\
\text { work, as openly as possible } \\
\text { - List of used references given by the } \\
\text { method of Harvard (examples are } \\
\text { given in the STP) } \\
\text { - At a later stage, the student will give } \\
\text { a complete Problem Resolution (PR) } \\
\text { approach, using the modelling } \\
\text { suggested when the solution } \\
\text { implementation be done }\end{array}$} & & 0.50 & $\begin{array}{l}\text {-It is normal for the pupil to be disoriented as } \\
\text { he is not accus tomed to working under the } \\
\text { scientific method } \\
\text { - Student makes reports handwritten } \\
\text { - It is not anything to be delivered as early }\end{array}$ \\
\hline 3 & New reformulation of the search criteria & $\begin{array}{l}\text { Very specific descriptors are provided } \\
\text { to generate an appropriate search: } \\
\text { dynamic system, linear system, linear } \\
\text { approach, controllability, robustness, } \\
\text { resonant systems,... }\end{array}$ & & 0.17 & 0.50 & \multirow{2}{*}{$\begin{array}{l}\text { At this stage any student needs facilitation to } \\
\text { be addressed in the right direction } \\
\text { - Real-time corrective feedback must be done } \\
\text { often, either because students react in a way } \\
\text { not intended, either because the expected } \\
\text { progress does not materialize in the expected } \\
\text { steps/phases }\end{array}$} \\
\hline 4 & New reformu lation of the search criteria & $\begin{array}{l}\text { The student is told about the most } \\
\text { productive topics of the subject }\end{array}$ & & & 0.25 & \\
\hline 5 & $\begin{array}{l}\text { Open formulat ion of the problem, to be solved } \\
\text { according to the PR methodology, clearly } \\
\text { incorporating the relationships linking the } \\
\text { proposal with other subjects of the Degree }\end{array}$ & $\begin{array}{l}\text { The student will have to develop the } \\
\text { theory underlying the model } \\
\text { presented, linking mathematics and } \\
\text { that interest area }\end{array}$ & $\begin{array}{l}\text { - The proposed statement should make } \\
\text { clear the rel ationship between } \\
\text { contents and descriptors in the } \\
\text { subject } \\
\text { - Analysis of the model: the theory } \\
\text { must be described succinctly and } \\
\text { directly }\end{array}$ & & 2.00 & $\begin{array}{l}\text { - The student usually shows difficulties when } \\
\text { verbalizing his/her work experience } \\
\text { - The difficulties that can lead the future } \\
\text { development of the project ought to be written }\end{array}$ \\
\hline 6 & $\begin{array}{l}\text { Design of way the implementation of the } \\
\text { solution will be addressed }\end{array}$ & $\begin{array}{l}\text {-Problem analysis } \\
\text { - Analysis tools that can be used } \\
\text { - Locate resources that will be needed }\end{array}$ & $\begin{array}{l}\text { - List of variables involved } \\
\text { - The student will prepare a concept } \\
\text { map, organigram or similar, where a } \\
\text { working and calculation strategy } \\
\text { will be provided, reasoning about its } \\
\text { key points }\end{array}$ & 0.50 & 1.00 & $\begin{array}{l}\text { - The student does not have a clear idea of the } \\
\text { tools to work as a top-down/bottom-up design } \\
\text { - The student does not adequately link to the } \\
\text { key concepts of the subject with the } \\
\text { experience in the Course Project: the concept } \\
\text { maps of the thematic units of the course must } \\
\text { be continuously be recalled }\end{array}$ \\
\hline 7 & Remember the theoretical concepts involved & $\begin{array}{l}\text { Summary of the descriptors most } \\
\text { needed to develop the Course Project }\end{array}$ & $\begin{array}{l}\begin{array}{l}\text { Concept map of the contents } \\
\text { covered }\end{array} \\
\end{array}$ & 0.17 & 0.50 & The student must be drawn to study daily \\
\hline 8 & $\begin{array}{l}\text { Deduction of the working model from the } \\
\text { graphical representation }\end{array}$ & $\begin{array}{l}\text { Analyze whether the problem is } \\
\text { discrete or continuous, clarify ing what } \\
\text { the variables are and the relationship } \\
\text { between them }\end{array}$ & $\begin{array}{l}\text { - Deduction of the theoretical model } \\
\text { - Justified and reasoned statement } \\
\text { of the working hypotheses, to } \\
\text { implement the resolution of the } \\
\text { problem }\end{array}$ & & 0.50 & $\begin{array}{l}\text { - Difficulties in discriminating the data and } \\
\text { results } \\
\text { - The variables are not discussed in the right } \\
\text { way } \\
\text { - No way are correct Descriptors and } \\
\text { keywords are not correctly expressed }\end{array}$ \\
\hline 9 & Refinement of the qualitative analys is & $\begin{array}{l}\text { Giv ing an overview of the whole } \\
\text { approach to see if mistakes take place }\end{array}$ & $\begin{array}{l}\text { Justified listing of the mistakes } \\
\text { appearing }\end{array}$ & & 0.50 & $\begin{array}{l}\text { The student does devote no time to review and } \\
\text { reflect }\end{array}$ \\
\hline 10 & $\begin{array}{l}\text { Analysis of the weaknesses of the approach by } \\
\text { the teacher }\end{array}$ & $\begin{array}{l}\text { Monitoring, normally permitted, the } \\
\text { student }\end{array}$ & & 0.50 & & $\begin{array}{l}\text { The facilitation session must be compulsory; } \\
\text { otherwise, the student does not come } \\
\text { voluntarily }\end{array}$ \\
\hline 11 & $\begin{array}{l}\text { Implementation the solution by solving } \\
\text { systems of linear equations in the sense of } \\
\text { least squares }\end{array}$ & $\begin{array}{l}\text { Calculate the para meters involved in } \\
\text { the model of the Course Project }\end{array}$ & Coherence of the results obtained & 0.17 & 1.50 & $\begin{array}{l}\text { The student often uses only pencil and paper, } \\
\text { not making use of ICT to enhance their overall } \\
\text { productivity }\end{array}$ \\
\hline 12 & Deduction of conclusions & $\begin{array}{l}\text { Answer in a way justified the } \\
\text { questions raised in the Course Project } \\
\text { discussion }\end{array}$ & $\begin{array}{l}\text { Results are correct and explanations } \\
\text { are well justified }\end{array}$ & & 0.50 & $\begin{array}{l}\text { There are numbers, no units are provided, and } \\
\text { typically the results obtained are not discussed }\end{array}$ \\
\hline 13 & $\begin{array}{l}\text { Oral presentation and/or written report for the } \\
\text { Course Project }\end{array}$ & $\begin{array}{l}\text { Perform a PowerPoint presentation } \\
\text { that summarizes all the essentials of } \\
\text { Course Project outcomes }\end{array}$ & $\begin{array}{l}\text { Quality of the report/presentation } \\
\text { following the criteria reported in the } \\
\text { valuation rubrics at the beginning of } \\
\text { the course }\end{array}$ & & 1.00 & $\begin{array}{l}\text { - There is not too much interest to generate a } \\
\text { document with enough presence to the } \\
\text { university level } \\
\text { - There is no autonomy when generating the } \\
\text { report of the Course Project }\end{array}$ \\
\hline 14 & $\begin{array}{l}\text { Evolution of the student's evolution and } \\
\text { progress in mastering the techniques involved } \\
\text { in the Course Project }\end{array}$ & $\begin{array}{l}\begin{array}{l}\text { Interview ( } 3 \text { sessions of } 10 \text { minutes) } \\
\text { with the teacher of the course on an } \\
\text { individual basis and with other group } \\
\text { members }\end{array} \\
\end{array}$ & Daily records & 0.50 & & $\begin{array}{l}\text { It is quite difficult to verbalize feelings and } \\
\text { emotions in front of a teacher, and more if } \\
\text { other students are there, albeit in a small group }\end{array}$ \\
\hline 15 & $\begin{array}{l}\text { Final evaluation of the work done with the } \\
\text { Course Project }\end{array}$ & $\begin{array}{l}\text { Personal interview } \\
\text { Team interview } \\
\text { Analysis of team data and student's } \\
\text { data }\end{array}$ & $\begin{array}{l}\text { Summative assessment of the Course } \\
\text { Project with the student's follow-up, } \\
\text { and the opinion of each group member }\end{array}$ & 0.25 & & $\begin{array}{l}\text { Initially, the student is reluctant to assess their } \\
\text { colleagues, provided that there is no group } \\
\text { mentality }\end{array}$ \\
\hline 16 & $\begin{array}{l}\text { Following the REDER philosophy the } \\
\text { learning-teaching process of the Course } \\
\text { Project is revie wed on an ongoing basis, which } \\
\text { has the corresponding control mechanisms }\end{array}$ & $\begin{array}{l}\text { Quality of the Course Project report } \\
\text { Oral presentation of the Course } \\
\text { Project } \\
\text { Student's self-evaluation }\end{array}$ & $\begin{array}{l}\text { Lejk's method to evaluate the team } \\
\text { guided work, that has done the } \\
\text { Course Project }\end{array}$ & & & $\begin{array}{l}\text { Students need to comment the assessment } \\
\text { results to themas immediate or mediate } \\
\text { feedback }\end{array}$ \\
\hline
\end{tabular}

Fig. 9. Flow diagram of the Course Project implementation (formative and additive assessment in blue colour).

S6: Which are the student's main difficulties? The PBL approach is an adequate tool to develop the problems, the algebraic descriptors usually pose: the vector space idea, different algebraic tools for numerical computation, situations where high dimensionality appears, systems with overdetermined data, the spectral theory to summarize systems up, the analysis of the physical systems response, ... 
S7: To establish the connections with other units of the syllabus or with other subjects of the degree: a good tutoring (namely, facilitation) is basic to adequately coach the team.

S8: The problem solving is made by a using a computer to emphasize the results discussion and to look for the appropriate explanations. Here, several problems can be detected which are related to the team/student's working way. Consequently, additional objectives must be defined and the corresponding activities implemented to solve these difficulties (Fig. 13).

S9: The team should look for other technical situations to compare with: electronic, mechanical, chemical, economic, biological, hydraulic, neurophysiological ... models.

S10: The solution is reported as a scientific article and an oral presentation is compulsory. The report includes: (1) a graphical plot, (2) the data preparation, (3) the mathematical model of the information, (4) a solving proposal, (5) the algebraic and numerical methods that have been used, (6) the results preparation, (7) the results obtaining, (8) the results interpretation and discussions and (9) the coherence of the supplied data and the analysis of the errors achieved. A help template is provided to do it.

S11: The student's opinion is essential: so that the team must write a short essay over the experience and each student must fulfil an opinion poll on the learning-teaching process. The following questions are suggested as a guide:

\footnotetext{
$\checkmark \quad$ Is the student satisfied?

$\checkmark \quad$ The student, gets a significant training in an efficient manner in order to acquire new competences, skills and/or procedural knowledge?

$\checkmark \quad$ Does he/she apply these new strategies in his/her curriculum in an appropriate way?

$\checkmark$ The changes that succeed in the student's learning-teaching process, do they improve the considered teaching system?
}

S12: The evaluation is inner and outer: at the beginning of the course the evaluation criteria are discussed with the students and some consensus is reached. Then, each team evaluates its work which is discussed with the professor in an interview (inner evaluation) and the remaining teams do evaluate the oral presentation, which must be given (outer evaluation) (see Figs. 9, 10 and 13).

There are many examples that can be used to develop the PBL approach to work in a Course Project at the University in a first course. Some examples (that can be coordinated with other subjects) are: the vibration analysis, the phase plane study, the approximation theory in a lot of environments -for instance, when tendencies are important, non-linear systems linearization, the discussion of the algebraic properties of (continuous time and discrete time) linear systems, ... Those examples allow to follow the student's progress (formative evaluation) and also to discuss his/her development (in the sense of evolution) (additive evaluation) from the measurable outcomes (Wolf, 1994; Stake, 2004). 


\section{Result discussion}

If nothing is said, the results provided are for the 2007/08's course. The mean time that a student has employed in the Project has been $t_{P F C}=12.30$ hours $(12 \%)$ (in class has been $t_{p}=3.55$ hours $(30 \%)$ and the self-work $t_{n p}=8.75$ hours $\left.(70 \%)\right)$ (Fig. 9). Fig. 10 is the Gantt's diagram of the Course Project timing during the semester (see Fig. 6). The students suggest in the individual reports that the initial project objectives are quite demanding, but the final questionnaire show great agreement.

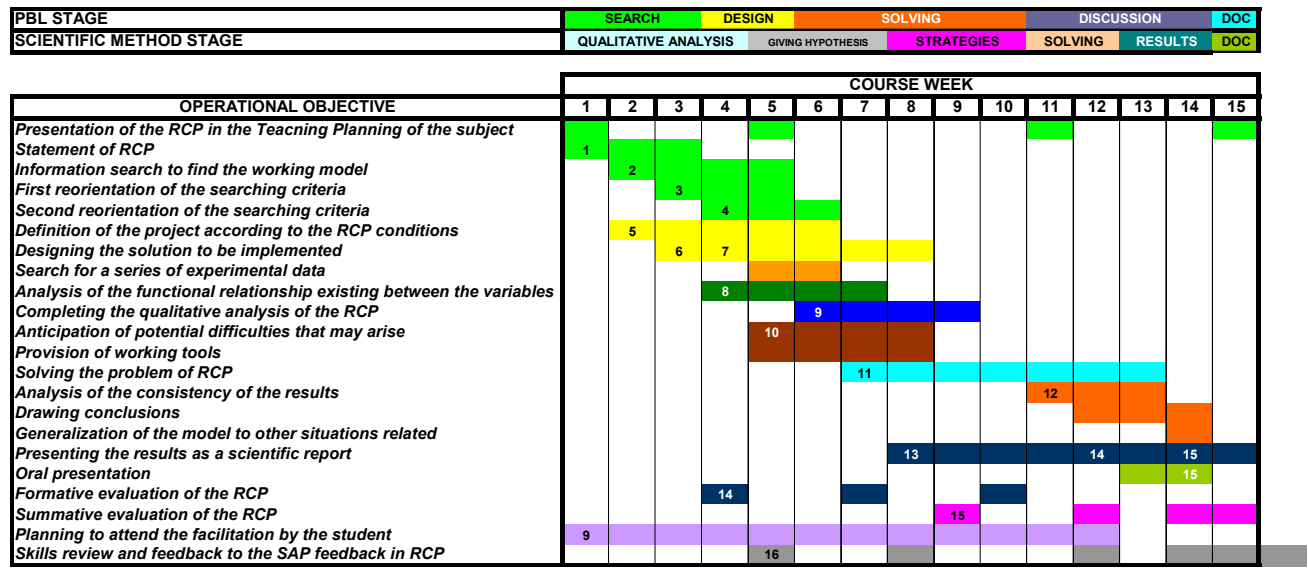

Fig. 10. The Gantt's diagram of the Course Project timing.

During this time period each student has done 1.24 (2004/05), 2.38 (2005/06) and 1.98 hours $(2007 / 08)$ of help session. The $96.34 \%$ has said that the tutoring session is an important task but only the $63 \%$ of the students has used it as a regular activity.

\begin{tabular}{|c|r|r|r|r|}
\cline { 2 - 5 } \multicolumn{1}{c|}{} & \multicolumn{4}{c|}{ Course Project (\%) } \\
\hline Qualification & $2004 / 05$ & $2005 / 06$ & $2006 / 07$ & $2007 / 08$ \\
\hline EXCELLENT $(Q>8.1)$ & 5 & & 10 & 87 \\
\hline VERY GOOD $(5.9<Q<8.1)$ & 37 & 57 & 65 & 13 \\
\hline GOOD $(3.2<Q<5.9)$ & 26 & 43 & 23 & 3 \\
\hline BAD $(Q<3.2)$ & 28 & & & 11 \\
\hline Team number & 9 & 5 & 7 & 32 \\
\hline Students' number & 37 & 15 & 35 & \\
\hline Registration number & 46 & 18 & & 35 \\
\hline
\end{tabular}

Fig. 11. Result summary of the Course Project additive evaluation.

Evaluation results are quite interesting (Fig. 11). A lot of students take the Course Project with quite good results, although teams are not big ( 3 or 4 people per group) and many students don't take the continuous evaluation (the causes are very diverse). There exist significant differences in 2004/05 and 2006/07 versus 2005/06 and 2007/08: the first ones correspond to 
morning courses (more academic) and the second ones to evening courses (students usually are working and they require a more practical treatment).

The students' opinion is going increasing every year. Results are quite good (Fig. 12) and they invite to use the PBL approach. However, these results can be improved, and the students can help in such a task.

\begin{tabular}{|l|c|}
\hline \multicolumn{1}{|c|}{ ITEM } & POSITIVE ANSWER \\
\hline OBJECTIVES EXPLANATION & $76 \%$ \\
\hline FORMATIVE PROGRAM UNDERSTANDING & $68 \%$ \\
\hline COURSE PROJECT COMPETENCES & $87 \%$ \\
\hline SUPPLIED INFORMATION & $78 \%$ \\
\hline PROFESSOR'S HELP & $89 \%$ \\
\hline THE COURSE PROJECT IN THE SUBJECT & $94 \%$ \\
\hline HAS LEARNED TO WORK IN A TEAM? & $75 \%$ \\
\hline WORK ENVIRONMENT & $96 \%$ \\
\hline WOULD YOU WORK AGAIN WITH THIS PROFESSOR? & $95 \%$ \\
\hline GENERAL QUALIFICATION OF THE COURSE PROJECT & $88 \%$ \\
\hline PROFESSOR'S QUALIFICATION & $87 \%$ \\
\hline
\end{tabular}

Fig. 12. Results of the 2007/08 student's opinion questionnaire.

\section{Facilitation}

When developing a PBL Project course great care must be devoted to the tutoring task, above all in the first courses (namely, this is the case where strengthening work in basic sciences is called for (Shuman et al., 2005)); namely, focusing on improving the student's communication (Hansen and Jensen, 2004). In this sense, facilitation must develop daily reflection: pre-session (to present a focus concerning group dynamics so that facilitative questions should be used to start reflection), ordinary supervision session (with timeouts to discuss focus and to play diverse roles) and post-session (to facilitate reflections on the focus). Furthermore, facilitation implies tutoring and supervision (sometimes, even control -see Figs. 9 and 10) to respond to student's problems in terms of meta-skills. Several dimensions are taken into account: the intellectual dimension, the personal dimension, the social dimension, the practical dimension (with several viewpoints: providing support, encouraging independence, developing the interpersonal) and assessing research (formative assessment, creativity and originality, reliability and validity) (Light and Cox, 2001).

However, the teacher's role must also be considered from a leadership point of view: from hierarchy/autocratic/consultative to autonomy/functional/contractual via cooperation/ negotiation/consultative. This implies that the student/teacher relationships ought to include six dimensions: the planning dimension (goal-oriented, aims, ends and means), the meaning dimension (cognitive understanding of experience), the confronting dimension (raising awareness to individual and group resistance), the feeling dimension (addressing emotional competence and incompetence), the structuring dimension (methodology of structuring experiences) and the valuing dimension (creating a support climate that celebrates individuals) (Gregory, 2002; Savin-Baden, 2003; Tosey and Gregory, 2001). Fig. 13 reports some of the tasks that are considered during the facilitation process of the Project Course. 


\begin{tabular}{|c|c|c|c|c|}
\hline \multicolumn{2}{|c|}{ ACTIVITY TO ASSESS } & COMPETENCE & APTITUDE FOCUSED & $\begin{array}{l}\text { QUESTION TO POSE/ } \\
\text { APPROACH COVERED }\end{array}$ \\
\hline $\begin{array}{l}\text { Looking for the best } \\
\text { information in an } \\
\text { optimum way }\end{array}$ & FA & $\mathrm{C} 4$ & $\begin{array}{l}\text { The individualization of the } \\
\text { LTP: task assignment }\end{array}$ & $\begin{array}{l}\text { References looked up and } \\
\text { constructed used } \\
\text { Time used to do the seeking }\end{array}$ \\
\hline $\begin{array}{l}\text { Definition of the open } \\
\text { problem based on the } \\
\text { given standards }\end{array}$ & $\mathbf{A A}$ & $\mathrm{C} 4$ & $\begin{array}{l}\text { Student's proactive } \\
\text { participation and implication }\end{array}$ & $\begin{array}{l}\text { Rigour and precision of the } \\
\text { approach proposed } \\
\text { The way in which is declared } \\
\text { the future implementation of the } \\
\text { Course Project } \\
\text { Adequate justification of the } \\
\text { choice posed }\end{array}$ \\
\hline $\begin{array}{l}\text { Role playing in the } \\
\text { team/group }\end{array}$ & FA & $\mathrm{C} 5$ & $\begin{array}{l}\text { Contribution to the } \\
\text { cooperative spirit of the } \\
\text { team/group }\end{array}$ & $\begin{array}{l}\text { Reasoning about the given role } \\
\text { playing proposal in the group } \\
\text { How the group worktable has } \\
\text { been accomplished? } \\
\text { Has the group productivity been } \\
\text { followed? How? Which tools } \\
\text { have been employed? }\end{array}$ \\
\hline $\begin{array}{l}\text { Forecasting of the } \\
\text { difficulties which could } \\
\text { come up/arise }\end{array}$ & FA & $\mathrm{C} 5$ & $\begin{array}{l}\text { Qualitative analysis of the } \\
\text { solution found out }\end{array}$ & $\begin{array}{l}\text { How can be interpreted the } \\
\text { resolution of any linear system } \\
\text { equation in an approximate } \\
\text { manner? } \\
\text { Can be a qualitative analysis of } \\
\text { the problem made? }\end{array}$ \\
\hline $\begin{array}{l}\text { Look for values to settle } \\
\text { the numeric problem } \\
\text { down }\end{array}$ & FA & $\mathrm{C} 4$ & $\begin{array}{l}\text { Coordination and linking } \\
\text { with other subjects of the } \\
\text { degree }\end{array}$ & $\begin{array}{l}\text { How the chosen data can be } \\
\text { disposed in order to apply the } \\
\text { algebraic theory of the syllabus? }\end{array}$ \\
\hline $\begin{array}{l}\text { Resolution approach } \\
\text { and formulation }\end{array}$ & FA & $\mathrm{C} 5$ & Task arrangement & $\begin{array}{l}\text { Which methodology type is } \\
\text { applied? } \\
\text { How the work is distributed } \\
\text { among the group members? } \\
\text { Is there any concept map about } \\
\text { the implementation developed? } \\
\text { A Gannt's diagram about times } \\
\text { and role playing has been } \\
\text { presented? }\end{array}$ \\
\hline $\begin{array}{l}\text { Result contrast related } \\
\text { to the planned outcomes }\end{array}$ & $\mathbf{A A}$ & $\mathrm{C} 4$ & $\begin{array}{l}\text { Coherence between the } \\
\text { obtained results and the } \\
\text { theory applied }\end{array}$ & $\begin{array}{l}\text { The results looked for have been } \\
\text { attained? } \\
\text { The values obtained, can be } \\
\text { justified? }\end{array}$ \\
\hline $\begin{array}{l}\text { Analysis of the } \\
\text { difficulties that have } \\
\text { been encountered }\end{array}$ & FA & $\mathrm{C} 4$ & Interesting contributions & $\begin{array}{l}\text { How have been solved the } \\
\text { encountered difficulties? } \\
\text { How the resources used have } \\
\text { been managed? } \\
\text { A problematic situation will be } \\
\text { suggested (it will be a direct } \\
\text { consequence of the project his/ } \\
\text { her group has worked }\end{array}$ \\
\hline $\begin{array}{l}\text { Implementation } \\
\text { computational costs }\end{array}$ & FA & $\mathrm{C} 5$ & Result contrast & $\begin{array}{l}\text { How the used method cost has } \\
\text { been measured? } \\
\text { Is there any cost study? }\end{array}$ \\
\hline $\begin{array}{l}\text { Teamwork applied } \\
\text { methods }\end{array}$ & $\mathbf{A A}$ & $\mathrm{C} 5$ & Self-assessment skills & $\begin{array}{l}\text { Quality of the self-assessment } \\
\text { report presented } \\
\text { Which values are pointed out by } \\
\text { his/her group-mates? }\end{array}$ \\
\hline $\begin{array}{l}\text { Scientific report of the } \\
\text { project experience }\end{array}$ & $\mathbf{A A}$ & $\mathrm{C} 4$ & $\begin{array}{l}\text { Helping the use of an } \\
\text { appropriate structure for the } \\
\text { project approach of the group }\end{array}$ & $\begin{array}{l}\text { How is used the mathematical } \\
\text { language and the formal } \\
\text { relations? How is it reasoned? }\end{array}$ \\
\hline $\begin{array}{l}\text { Oral presentation of the } \\
\text { report }\end{array}$ & $\mathbf{A A}$ & $\mathrm{C} 5$ & $\begin{array}{l}\text { Coherence of the defence } \\
\text { presented }\end{array}$ & $\begin{array}{l}\text { Reasoned justification of the } \\
\text { report presentation carried out }\end{array}$ \\
\hline $\begin{array}{l}\text { Last interview for } \\
\text { assessment }\end{array}$ & FA & C5 & $\begin{array}{l}\text { Use of the procedural } \\
\text { knowledge related to the } \\
\text { subject }\end{array}$ & $\begin{array}{l}\text { How does the student answer } \\
\text { the questions that have been } \\
\text { posed? }\end{array}$ \\
\hline $\begin{array}{l}\text { Attitude in the } \\
\text { facilitation and } \\
\text { tutoring times }\end{array}$ & FA & $\mathrm{C} 4$ & $\begin{array}{l}\text { A more emphatic } \\
\text { relationship between } \\
\text { undergraduates/students and } \\
\text { the teaching staff }\end{array}$ & $\begin{array}{l}\text { Is there a positive attitude in the } \\
\text { group structure running? } \\
\text { The group, does it appear open- } \\
\text { minded, active, productive, } \\
\text { efficient, effective, ...? } \\
\text { A given student, which is the } \\
\text { position that shows in the } \\
\text { presence of his/her group- } \\
\text { mates? }\end{array}$ \\
\hline
\end{tabular}

Fig. 13. Some questions that are posed to students along the help/tutoring sessions (FA means formative assessment; AA stands for additive assessment). 


\section{Conclusions}

An application tour to a Problem-Based Learning approach has been reported. In contrast to other approaches, PBL not only emphasizes the work on the case study, self study and knowledge transfer among group members, but also the process of team work and the quality of the solution found by the students. With PBL an elaborate concept is presented; from the learning targets for our students to the marking all elements are well-coordinated. The aim of all the pedagogical efforts is to provide our students with decision-making and responsibility for their future vocational field. We analyze the possibilities of a course project based on the PBL methodology for teaching problem solving: its strengths and its weaknesses are emphasized. In other words, we conceive the possibility of proposing a vision for overcoming the teaching methods of problem solving in Science and Engineering, which in line with the model of learning as a research-oriented, leads to a methodological change in a way that the students arrive to be able to cope more successfully open-statement problems, for their educational level. The proposal is not characterized by dramatic changes in the structure of the education system but for qualitative changes in the teaching strategies used in the classroom, the activities proposed by the students and by the sequencing of conceptual and methodological contents. All this involves a series of changes at three levels: a) changes in the task, b) changes in the structure of the class, and c) changes in its operation.

The resolutions of problems by students accustomed to implement the proposed model, features closely the characteristics of the 'scientific work' and increase its effectiveness as resolvents. The procedural knowledge involves declarative knowledge specific to the area, and at the same time, the acquisition of the declarative knowledge is a process of construction that makes implicit or explicit use of procedural knowledge. It is therefore reasonable to expect that the further development of those procedures could lead to a more comprehensive learning and greater efficiency in the resolution. Since 2002 we have been working quite successfully with this student-centered method in our regular curricula and the enhancement is everyday in progress:

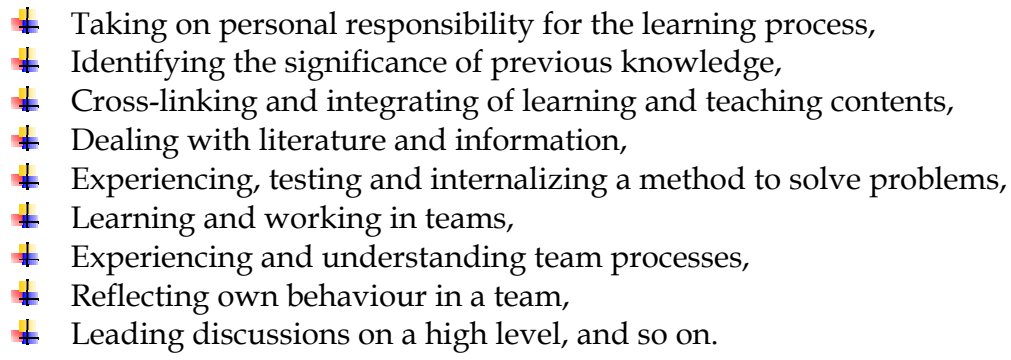

\section{Acknowledgements}

The authors are very grateful to the University of the Basque Country for the partial support of this work through Project EHU 06/46. 


\section{References}

Albert, M.J. (2007). La investigación educativa: Claves teóricas. ISBN 978-84-481-5942-9, Madrid, McGraw-Hill.

Barrows, H.S. (2006): Problem-Based Learning in Medicine and Beyond: A Brief Overview. New Directions for Teaching and Learning, 68, 3-12, ISSN 0271-0633, Wiley Periodicals.

Brockbank, A. \& McGill, I. (2003). Aprendizaje reflexivo en la Educación Superior. ISBN 8471124521, Morata, Madrid.

Castillo, S. \& Polanco, L. (2007), Enseña a estudiar...Aprende a aprender: Didáctica del estudio. ISBN 84-205-4285-7, Pearson/Prentice Hall, Madrid.

Fullan, M. (2002), Los nuevos significados del cambio en la educación. ISBN 8480635509, Octaedro, Barcelona.

Gregory, J. (2002). Facilitation and Facilitator Style. In: The Theory \& Pratice of Teaching (Jarvis, P., Ed.), ISBN 0749434164, Kogan Page Ltd., London.

Hansen, S. \& Jensen, P. (2004). Supervisión and Group Dynamics. In: The Aalborg PBL model : progress, diversity and challenges, Kolmos, A.; Fink, F.K. \& Krogh, L. (Eds.), ISBN 8773077003, Aalborg University, Danemark.

Light, G. \& Cox, R. (2001). Learning and Teaching in Higher Education: The Reflective Professional. ISBN 0761965521, Paul Chapman Pub., SAGE Pub. Co., London.

McKernan, J. (1999). Investigación-ación y currículum: Métodos y recursos para profesionales reflexivos. ISBN 9788471124388, Ediciones Morata, S.L., Madrid.

Michavila Pitarch, F. (coordinator) (2006): Propuestas para la renovación las metodologías docentes en la Universidad. Consejo de Coordinación Universitaria (Secretaría de Estado de Universidades e Investigación, Ministerio de Educación y Ciencia) y Cátedra UNESCO de Gestión y Política Científica (Universidad Politécnica de Madrid). Madrid.

Phillips, D. C. (1995), The Good, the Bad, and the Ugly: The Many Faces of Constructivism. Educational Researcher, 24(7), october-1995, 5-12, ISSN 0013189X06298001.

Shuman, L.J.; Besterfield-Sacre, M. \& McGourty, J. (2005). The ABET “Professional Skills" Can They Be Taught? Can They Be Assessed?, Journal of Engineering Education, 94(1), January-2005, 41-55.

Savin-Baden, M. (2000). Problem-based Learning In Higher Education: Untold Stories. ISBN 9780335203376, McGraw-Hill, New York.

Savin-Baden, M. (2003). Facilitating Problem-Based Learning: Illuminating Perspectives. ISBN 0335210541, Open University Press, Bershire, England.

Stake, R. E. (2004). Standards-based and responsive evaluation. ISBN 0761926658, Sage Publications, Inc., London.

Tosey, P. \& Gregory, J. (2001). Dictionary of Personal Development. ISBN 1861562810, Whurr Pub., London.

Wertz, V.; Ben-Naoum, K. \& Delsarte, P. (2005). PBL in Mathematics: What is a "Good" Problem?, Int. Conf. on Problem-Based Problems. June, 2005, Lahti, Finland.

Wolf, R. M. (1994): The Validity and Reliability of Outcome Measure. In: Monitoring the Standards of Education. Tuijnman, A.C. \& Postlehwaite, T.N. (Eds.), pp. 121-132, ISBN 0415368782, Pergamon, Oxford. 


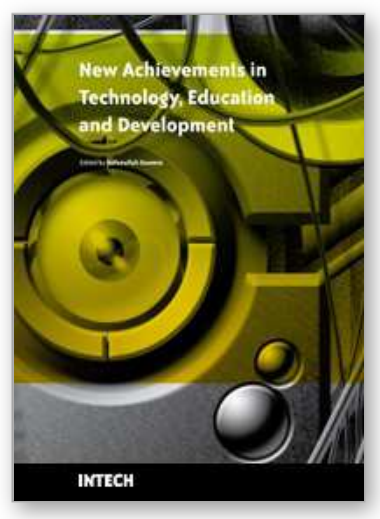

\author{
New Achievements in Technology Education and Development \\ Edited by Safeeullah Soomro
}

ISBN 978-953-307-066-7

Hard cover, 460 pages

Publisher InTech

Published online 01, March, 2010

Published in print edition March, 2010

Since many decades Education Science and Technology has an achieved tremendous recognition and has been applied to variety of disciplines, mainly Curriculum development, methodology to develop e-learning systems and education management. Many efforts have been taken to improve knowledge of students, researchers, educationists in the field of computer science and engineering. Still many problems to increase their knowledge on daily basis so this book provides newly innovations and ideas in the field of computer science and engineering to face the new challenges of current and future centuries. Basically this book open platform for creative discussion for future and current technologies to adapt new challenges in education sector at different levels which are essential to understand for the students, researchers, academic personals and industry related people to enhance their capabilities to capture new ideas and provides valuable contribution to an international community.

\title{
How to reference
}

In order to correctly reference this scholarly work, feel free to copy and paste the following:

Juan Carlos Soto Merino (2010). A Course Project: An Overview from the PBL 'as-Research-Oriented' Viewpoint, New Achievements in Technology Education and Development, Safeeullah Soomro (Ed.), ISBN: 978-953-307-066-7, InTech, Available from: http://www.intechopen.com/books/new-achievements-intechnology-education-and-development/a-course-project-an-overview-from-the-pbl-as-research-orientedviewpoint

\section{INTECH}

open science | open minds

\section{InTech Europe}

University Campus STeP Ri

Slavka Krautzeka 83/A

51000 Rijeka, Croatia

Phone: +385 (51) 770447

Fax: +385 (51) 686166

www.intechopen.com

\section{InTech China}

Unit 405, Office Block, Hotel Equatorial Shanghai

No.65, Yan An Road (West), Shanghai, 200040, China

中国上海市延安西路65号上海国际贵都大饭店办公楼405单元

Phone: +86-21-62489820

Fax: +86-21-62489821 
(C) 2010 The Author(s). Licensee IntechOpen. This chapter is distributed under the terms of the Creative Commons Attribution-NonCommercialShareAlike-3.0 License, which permits use, distribution and reproduction for non-commercial purposes, provided the original is properly cited and derivative works building on this content are distributed under the same license. 